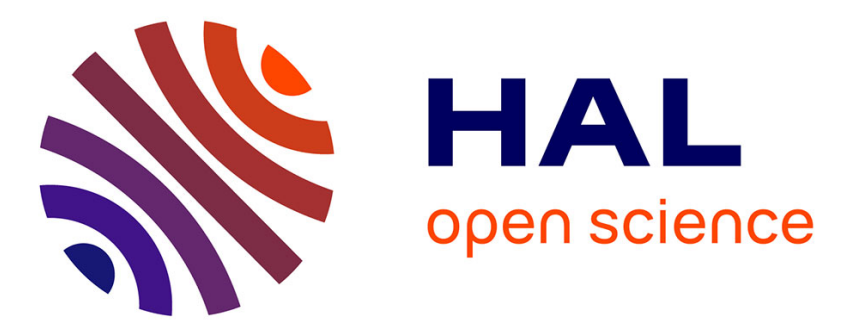

\title{
Open H-Shape Ferrite Permanent Magnet Structure for NMR Imaging
}

\author{
V. Nguyen, J. Delamare, J.-P. Yonnet
}

\section{To cite this version:}

V. Nguyen, J. Delamare, J.-P. Yonnet. Open H-Shape Ferrite Permanent Magnet Structure for NMR Imaging. Journal de Physique IV Proceedings, 1997, 07 (C1), pp.C1-139-C1-140. 10.1051/jp4:1997147 . jpa-00255094

\section{HAL Id: jpa-00255094 https://hal.science/jpa-00255094}

Submitted on 1 Jan 1997

HAL is a multi-disciplinary open access archive for the deposit and dissemination of scientific research documents, whether they are published or not. The documents may come from teaching and research institutions in France or abroad, or from public or private research centers.
L'archive ouverte pluridisciplinaire HAL, est destinée au dépôt et à la diffusion de documents scientifiques de niveau recherche, publiés ou non, émanant des établissements d'enseignement et de recherche français ou étrangers, des laboratoires publics ou privés. 


\title{
Open H-Shape Ferrite Permanent Magnet Structure for NMR Imaging
}

\author{
V. Nguyen, J. Delamare and J.-P. Yonnet \\ Laboratoire d'Electrotechnique de Grenoble, ENSIEG, BP. 46, 38402 Saint-Martin-d'Hères cedex, \\ France
}

\begin{abstract}
In this paper we propose a new NMR structure. The system is composed of ferrite magnets and has an open-Hshape. It has been calculated theorically. A prototype has been manufactured using specific ferrite machining techniques which we presente here. The prototype has been measured, the shimming procedure has been started.
\end{abstract}

Magnetic resonance imaging has become in recent years one of the most important tools for medical diagnoses by visualizing simultaneously both hard and soft tissues within the human body. For this application, a very uniform static field is required. Typically, for an whole body system, the magnetic field must achieve a uniformity of a few ppm over a $300 \mathrm{~mm}$ diameter sphere and the field is about $1,5 \mathrm{~T}$. Nowadays engineering techniques for increasing spatial resolution or reducing scanning times are well known and the field strength is therefore no longer so consequential. Therefore NMR imaging at low field is now technically possible and the use of ferrites has to be considered as direct competitors to rare earth permanent magnets, because of their much cheaper price.

\section{PRESENTATION OF A NEW NMR FERRITE MAGNET STRUCTURE}

\subsection{Description of the structure}

We propose a new open $\mathrm{H}$-shaped ferrite magnet structure. The system is composed of two magnet disks generating the main flux, with two magnet rings improving the homogeneity. All pieces are axially magnetized. An iron yoke controls the flux return and reduces the leakage flux (Fig. 1). The structure is attractive because of its simplicity and its open shape. It is also easy to build and magnetize.

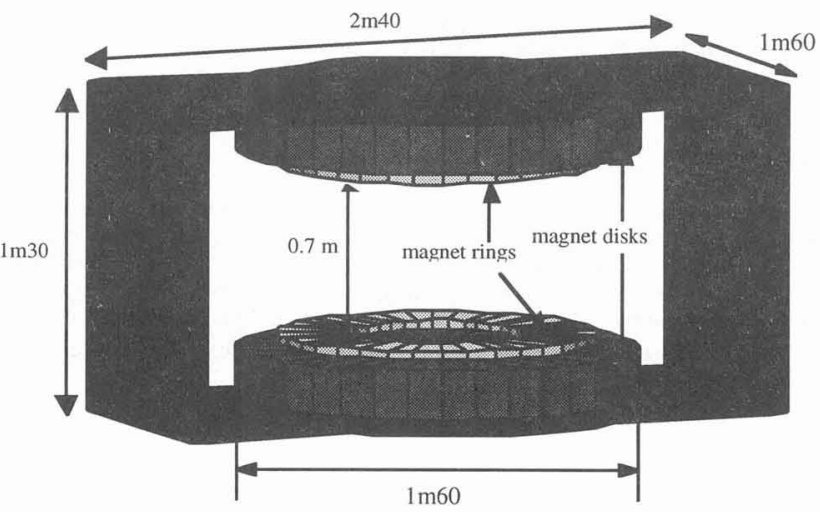

Figure 1: Geometry of the NMR structure

This structure has been theorically calculated using the software Dipôle3D which we have developed.[1], [2] The field at the center of the structure is about $0,1 \mathrm{~T}$.

\subsection{Machining technics}

A prototype has been built with ferrite magnets. Ferrites are non conductive materials and the electroerosion technique can therefore not be applied. Moreover ferrites are hard and brittle ceramics, and specific precautions have to be taken to avoid breaking the magnets. We present several machining techniques adapted to the ferrite material we have tested. 
The gush of water technique can be used (Fig.2 a and b). This technique is advantageous for rapidly machining complex forms or big ferrite pieces. Moreover the mechanical and thermal strains are reduced. However the cutting accuracy is often more than $0.1 \mathrm{~mm}$. The surface is rough as soon as the squirt speed is too high and cavities are made by the gush where it enters or exits the profile of the cutting. The figures below show the cutting of a disk and the straight cutting of a ferrite cube.

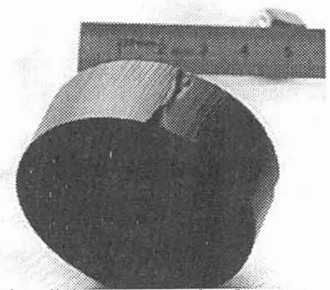

a) Ferrite disk cut by gush of water Figure 2: $\quad$ Ferrite pieces cut by gush of water

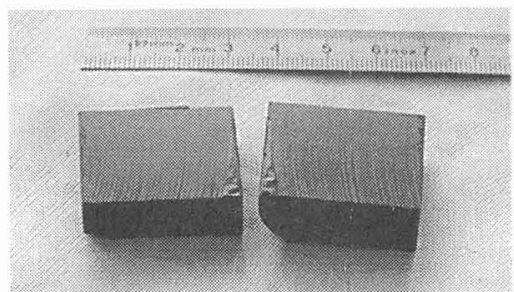

b) Ferrite cube cut into two pieces by gush of water

In order to improve the accuracy, diamond tools can be used:

Concerning the straight cutting, the use of a diamond disk with plentyful lubrification is the most adapted.

Concerning the circular cutting, several solutions can be used. The first one consists in using a diamond circular slitting saw wich trepans the media as a trepan tool does. The second one concerns the use of polycristalline diamond tools. The surface quality is really satisfying. We have straightened a face of a ferrite parallelepiped. Figure 3 shows the pieces we have obtained. The black peripheral marks on the face of figure b) correspond to the material defects.

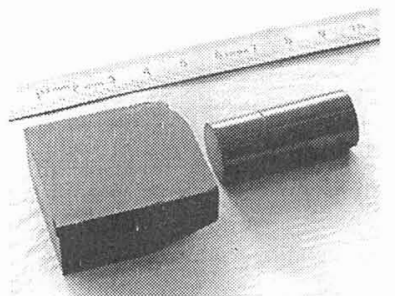

a) Cylinder lathe-turned

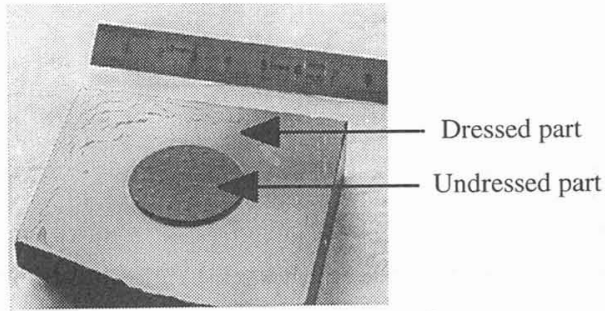

b) Face of a parallelepiped lathe-turned

Figure 3: Lathe-turned ferrite with polycristalline diamond tool

\subsection{Realisation of a prototype}

Thanks to the diamond techniques we have realised a prototype (scale $1: 5$ ) of the proposed structure. The magnet disks and rings were composed of several ferrite blocks placed close to each other and machined together. Then the ferrites have been individually magnetized. Compared to the Rare-Earth magnetic characteristics, ferrites have a lower coercitive field. This is the reason why the problem of the demagnetization has been studied and an operating procedure has been determined. The ratio height/width of the ferrites blocks must be as big as possible and each block has to be brought tangentially to the yoke and not vertically.

\subsection{Measurement of the prototype}

In our case, the different main causes of the field inhomogeneity are the dispersion of the ferrite magnetic charactistics and the tolerances of the realization. Two ferrite pieces never have exactly the same magnetization. A overall variation of about $2 \%$ has been measured for the ferrite pieces we used. We remark for example that the field variations along the $z$ axis were not symmetric although the structure is. We have first added circular pole pieces on the rings. Consequently, the field curves exactly respect the symetries of the geometry. Then we have added extra pole pieces near the poles. By rolling these pieces we modify the field curves. Thanks to this simple adjustment procedure we achieve today a relative homogeneity of a few $10^{-4}$ over $6 \mathrm{~cm}$ (scale 1:5) along the three axes.

\section{CONCLUSION}

A new NMR system has been proposed in this article. The structure is open, presents a very reduced flux leakage and is simple to manufacture. Since the dimensions of the structure have been theorically determined for a uniform field, the homogeneity of the manufactured structure is improved thanks to simple corrections.

\section{References}

[1] J. Delamare, E. Olivier-Rulliere, J-P. Yonnet, 3D calculation of permanent magnet interactions, IMACS TC'1 93, July 93, p. 289-292.

[2] C.E. Vidigal, Methode de calcul de champ magnétique pour IRM avec aimant permanent et fer, Thèse de Doctorat, Orsay, 1992. 